\title{
Incorporation of Independent Agencies into the Executive Branch
}

The independence of certain federal agencies ${ }^{1}$ from the executive branch dates to the 1935 decision of Humphrey's Executor v. United States. ${ }^{2}$ The Supreme Court there held that the distinctive expertise and impartiality of certain agencies justified the power of Congress to insulate agency officers from removal at will by the President. The case was part of a general acceptance of a practical and flexible, or "functional", approach to separation of powers-an approach that has led to independent agencies being considered a "veritable fourth branch" of government."

Today, the foundations of Humphrey's Executor are crumbling. From the functionalist perspective, the distinctive expertise and impartiality of independent agencies appear much less compelling in the light of a halfcentury of experience. Other functional arguments, such as the need for greater coordination and accountability in agency action, now counsel against independence. In addition, the new formalism of recent separation of powers cases, most notably INS v. Chadha, ${ }^{4}$ suggests a doctrinal challenge to the entire functionalist approach implicit in Humphrey's Executor. The Court instead has reemphasized the Constitution's provision for three and only three branches. In sum, on both functional and formal grounds, this Note argues that Humphrey's Executor should now be discarded, and independent agencies incorporated into the executive branch.

1. President Reagan's Exec. Order No. 12,291, § 1(d), 3 C.F.R. $§ 127$ (1982), exempts, as independent, those agencies specified in 44 U.S.C. $\$ 3502(10)$ (Supp. V 1981). This section provides:

[T] he term "independent regulatory agency" means the Board of Governors of the Federal Reserve System, the Civil Aeronautics Board, the Commodity Futures Trading Commission, the Consumer Product Safety Commission, the Federal Communications Commission, the Federal Deposit Insurance Corporation, the Federal Energy Regulatory Commission, the Federal Home Loan Bank Board, the Federal Maritime Commission, the Federal Trade Commission, the Interstate Commerce Commission, the Mine Enforcement Safety and Health Review Commission, the National Labor Relations Board, the Nuclear Regulatory Commission, the Occupational Safety and Health Review Commission, the Postal Rate Commission, the Securities and Exchange Commission, and any other similar agency designated by statute as a Federal independent regulatory agency or commission.

Since the promulgation of Exec. Order No. 12,291, the Civil Aeronautics Board has been disbanded, 49 U.S.C.A. \& 1551 (West Supp. 1984), and the Commission on Civil Rights has become independent by statute. United States Commission on Civil Rights Act of 1983, Pub. L. No. 98-183, § 2(d), 97 Stat. 1301 (1983) (codified at 42 U.S.C.A. $\$ 1975$ (West Supp. 1984)).

2. 295 U.S. 602 (1935).

3. FTC v. Ruberoid Co., 343 U.S. 470, 487 (1952) (Jackson, J., dissenting). As early as 1937, a report to the President attacked independent agencies as a "headless fourth branch" of government. President's Comm. on Administrative Management, Administrative Management in the Government OF THE U.S. 36 (1937). See Strauss, The Place of Agencies in Government: Separation of Powers and the Fourth Branch, 84 Colum. L. REv. 573 (1984).

4. 462 U.S. 919 (1983). 


\section{Agency Independence and the Rise of Functionalism}

The modern law of removal began in 1926, in Myers v. United States, ${ }^{5}$ which involved the President's removal of a first-class postmaster without the statutorily-required concurrence of the Senate. Chief Justice Taft delivered a strongly formalist opinion, emphasizing the division of all governmental power into exactly three branches, ${ }^{\circ}$ and stating the principle that branches must be kept separate except where explicitly "blended" by the Constitution. ${ }^{7}$ The Court held removal to be an exclusively executive power, and thus not subject to congressional limitation. ${ }^{8}$

Nine years later the Supreme Court sharply limited Myers in Humphrey's Executor, ${ }^{\circ}$ which still provides the primary legal basis for agency independence. ${ }^{10}$ The case invalidated President Roosevelt's removal, contrary to statute, of Federal Trade Commissioner Humphrey. The distinctive character of Humphrey's office permitted Congress to limit the President's removal power. ${ }^{11}$ The duties of the Commission were "neither political nor executive,"12 and the Commission's special expertise and impartiality justified independence from the President. ${ }^{13}$ The President's "exclusive removal power," established in Myers, ${ }^{14}$ thereafter extended only to "purely executive" officers. ${ }^{18}$

The decision of Humphrey's Executor was part of a major shift to functionalism after 1935. The Supreme Gourt relaxed the Myers rule that all governmental actions had to fit into one of the three formal boxes of legis-

5. 272 U.S. 52 (1926). Contemporary observers considered the case a major event; the Court had previously avoided ruling on the power of the President to remove an officer in the face of a contrary statute. A contemporary observer corroborated the importance of the case in a way surprising to modern Court observers: "Not since 1899 . . . had a supreme court decision on a constitutional question captured a prominent place-with headlines to match-on the front page of the morning paper." E. Corwin, The President's Removal Power Under the Constitution at v (1927).

6. 272 U.S. at 116.

7. "[T]he reasonable construction of the Constitution must be that the branches should be kept separate in all cases in which they were not expressly blended, and the Constitution should be expounded to blend them no more than it affirmatively requires." Id. Accord Kilbourn v. Thompson, 103 U.S. 168, 190-91 (1880).

8. The Court said the case presented the question whether "the President has the exclusive power of removing executive officers of the United States whom he has appointed by and with the advice and consent of the Senate." 272 U.S. at 106.

9. 295 U.S. 602 (1935).

10. See Robinson, The Federal Trade Commission: An Essay on Regulatory Watchdogs, 64 VA. L. REv. 169, 207-08 n.89 (1978) (Humphrey's Executor remains primary case on agency independence).

11. 295 U.S. at 631 .

12. Id. at 624 .

13. "[I]ts members are called upon to exercise the trained judgment of a body of experts . . . ." Id. "The Commission is to be non-partisan; and it must, from the very nature of its duties, act with entire impartiality. It is charged with the enforcement of no policy except the policy of the law." Id.

14. 272 U.S. at 106.

15. 295 U.S. at 632 
lative, executive, or judicial action. ${ }^{16}$ Academic commentators and the courts supported the New Deal's institutional innovations-hybrid organs of government with blended powers. ${ }^{17}$ By 1952, Justice Jackson's influential concurrence in Youngstown Sheet E Tube Co. v. Sawyer ${ }^{18}$ proposed a separation of powers doctrine premised on flexibility, ${ }^{10}$ practicality, ${ }^{20}$ and judicial reluctance to enforce the doctrine based on isolated parts of the Constitution. ${ }^{21}$ Functionalism was dominant, but by 1983, when Justice White followed the functionalist approach closely in INS v. Chadha, ${ }^{22}$ no other justice joined his dissent.

\section{FunCtionalism AND AgENCY INDEPENDENCE}

\section{A. Undermining of Functional Justification for Independence}

The erosion of the original functional justification for independence, combined with the lack of any contemporary difference in agency practice, leads to the conclusion that there is nothing distinctive today about independent agencies that deserves special protection.

16. The majority in Myers required all government actions to fit into one of the three branches. 272 U.S. at 116. See also Kilbourn v. Thompson, 103 U.S. 168, 190-91 (1880) (same requirement of tripartitism). Humphrey's Executor paid lip service to the separation of government into three branches, piously expounding "[t]he fundamental necessity of maintaining each of the three general departments of government entirely free from the control or coercive influence, direct or indirect, of either of the others." 295 U.S. at 629. The opinion's tolerance of the FTC as "predominantly quasijudicial and quasi-legislative," $i d$. at 624 , and hence outside of any of the three branches, shows that the Court observed the "fundamental necessity" only in language and not in substance.

By 1940, the Court quickly disposed of a claim that an administrative agency, not part of the judicial system, could not exercise "judicial power." Sunshine Anthracite Coal Co. v. Adkins, 310 U.S. 381 (1940). In Yakus v. United States, 321 U.S. 414, 424 (1944), the Court made clear its functionalist philosophy: "The Constitution as a continuously operative charter of government does not demand . . . the impracticable." But see INS v. Chadha, 462 U.S. 919, 959 (1983) (adherence to constitutional text required even though it can "impose burdens on government process that often seem clumsy, inefficient, even unworkable").

17. The leading exposition was J. Landis, The Administrative Process 15 (1938). See also Stewart, The Reformation of American Administrative Law, 88 HARV. L. REv. 1667, 1676-81 (1975) ("theory of expertise" dominant in administrative law after 1935).

18. 343 U.S. 579, 634-55 (1952).

19. Jackson proposed "flexible tests" of presidential power that "depend on the imperatives of events and contemporary imponderables rather than abstract theories of law." Id. at 637, 639.

20. Jackson gave "to the enumerated powers the scope and elasticity afforded by what seem to be reasonable, practical implications instead of the rigidity dictated by a doctrinaire textualism." Id. at 640.

21. "The actual art of governing under our Constitution does not and cannot conform to judicial definitions of the power of any of its branches based on isolated clauses or even single Articles torn from context." Id. at 635.

22. White quoted extensively from Justice Jackson's Youngstown opinion. 462 U.S. 919, 978 (1983) (White, J., dissenting). White's dissent specifically agreed with Jackson's theory of flexibility in separation of powers: "[O]ur Federal Government was intentionally chartered with the flexibility to respond to contemporary needs without losing sight of fundamental principles." Id. White's quotation points to an easily-overlooked similarity between functionalism and formalism. Both approaches can stress the importance of following the constitutional text; White's functionalism demonstrates, however, the possibility of understanding the text to require flexibility. At issue are canons of interpretation, not reliance on the Constitution vel non. 


\section{Decline in the Ideals of Expertise and Impartiality}

A rationale of Humphrey's Executor was that the desirability of fostering scientific expertise justified independence of agencies from contamination by the political process. ${ }^{23}$ Widespread skepticism toward such agency claims to expertise has since emerged. ${ }^{24}$ Critics have noted that agencies are prone to "capture" by regulated interests; ${ }^{25}$ agencies' independent, expert judgment is compromised by pressures to please the regulated community. Studies have concluded that agency personnel seek to maximize agency turf rather than any broader public interest. ${ }^{28} \mathrm{~A}$ series of reports have concluded that agencies have consistently failed to attract high quality personnel deserving of the term "expert."27 Finally, agencies have failed to achieve objective expertise even for what would seem strictly technical matters, such as nuclear power. ${ }^{28}$

Congress has responded to these criticisms, not by reenforcing the independence of "expert" agencies, but rather by attempting to ensure agency

23. 295 U.S. 602,625 (1935). The Court recognized the intent of Congress to create a body of experts, $i d$, and accepted Congress' characterization of the agency as distinct from executive agencies, id. at 628; see also Breyer, Afterword, 92 YALE L.J. 1614, 1615-16 (1983) (1930's ideal of expert, scientific administration).

24. Critics on both the political left and right have explained the history of passage of regulation and regulatory legislation as the use of governmental powers for sectional or private gain-the opposite of regulation viewed as the triumph of apolitical expertise. Compare G. Kolko, RAILroADS AND Regulation, 1877-1916, at 239 (1965) (progressivism as the triumph of "political capitalism") with Stigler, The Theory of Economic Regulation, 2 BELI J. EcoN. \& MGMr. ScI. 3, 3 (1971) (neoclassical economic theory that regulation is "designed and operated primarily for [industry's] benefit"). For a review of part of the immense literature, see Levine, Revisionism Revised? Airline Deregulation and the Public Interest, LAw \& Contemp. ProBs., Winter 1981, at 179 \& n.2.

25. According to this theory, administrators, in low visibility positions and cut off from political accountability, become "captured" by the regulated interests, upon whom they depend for information and for whom they often work upon leaving the agency. See M. BERNSTEIN, REGULATING Business BY INDEPENDENT Commission 155-60 (1955); T. LowI, The END of Liberalism: Ideology, Policy, AND THE CRisis of PUBlic AUThority 72-93 (1969). In a related theory, Olson has shown the advantages of small size to the achievement of collective benefits to a group. See M. OLsoN, The Logic of Collective Action: Public Goods and the Theory of Groups 33-36 (1971). In accord with this theory, agencies may well be subject to lobbying by small, well-organized groups (such as an industry lobby) disproportionate to that by larger groups (such as a consumer lobby). The larger groups can often offer only diffuse benefits to members-benefits which in many cases will not be sufficient to justify the costs of political participation.

26. See R. Arnold, Congress and the Bureaucracy: A Theory of Influence 20-21 (1979); W. Niskanen, Bureaucracy and Representative Government 36, 42 (1971).

27. See, e.g., J. Landis, Report on Regulatory Agenctes to the President-Elect 137-39 (1960); U.S. CoMm'N ON ORGaNization OF THE EXeCUTIVE BRANCH OF THE GOv'T, ThE HoOver Comm'n Report on Organization of THE EXecutive Branch of the Government 431 (1949); U.S. President's Advisory Council on Executtve Organization, A New Regu-

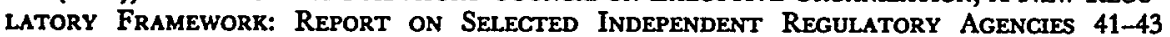
(1971).

28. The extremely technical nature of nuclear power has not protected the Nuclear Regulatory Commission, and its predecessor, the Atomic Energy Commission, from recurrent charges of incompetence and of bias in favor of nuclear power and against safety. See, e.g., R. NADER \& J. ABBOTTS, The Menace of Atomic Energy 273-83 (rev. ed. 1979). The possibility of value-free science, a logical predicate for the exercise of power by neutral experts, has itself been sharply challenged. See Bazelon, Coping with Technology Through the Legal Process, 62 CoRNELL L. REv. 817, 819 (1977). 
accountability. Recent statutes have constrained discretion with a variety of "agency-forcing" procedures. ${ }^{29}$ Most prominently, Congress attempted to ensure accountability through widespread statutory use of the legislative veto ${ }^{30}$ - a device that substituted the judgment of Congress for that of the supposedly expert agency. ${ }^{31}$ Thus, expertise is not only an ideal that agencies have failed to achieve, but also one largely irrelevant to a contemporary evaluation of agency independence.

The ideal that agency impartiality requires independence from political pressures has experienced a similar decline. The criticisms of expertise, such as agency "capture," also suggest that agencies are not impartial. The increased and widely accepted use of rulemaking, ${ }^{32}$ with its balancing of political considerations, has deliberately reduced agency insulation from external political debate. ${ }^{33}$ The widespread statutory employment of the legislative veto indicates that Congress values accountability more highly than independence from political concerns. ${ }^{34}$ In addition, within each agency, the level of impartiality required of individual decisionmakers has been substantially reduced. ${ }^{35}$

29. See B. Ackerman \& W. Hassler, Clean Coal/Dirty AIr 3-12 (1981) (history and motivation of congressional desire to prescribe agency implementation of statutes).

30. The legislative veto was held unconstitutional in INS v. Chadha, 462 U.S. 919 (1983). See infra text accompanying notes 81-93. Judge Breyer has defined the legislative veto as "a clause in a statute, which says that a particular executive [or independent agency] action . . . will take effect only if Congress does not nullify it by resolution within a specified period of time." Breyer, The Legislative Veto After Chadha, 72 GEO. L.J. 785, 785 (1984).

31. See cases cited infra note 92 .

32. Between 1962 and 1978 over forty major pieces of legislation were passed dealing with health, safety, and environmental regulation. R. LITAN \& W. NoRdhaus, Reforming FEdERAL RegulaTroN 44 (1983). The implementation of this mass of legislation occurred largely through rulemaking, which offered several advantages over case-by-case adjudication: Rules are published and prospective; they provide standards for measuring legality and constraining agency discretion; they offer procedural and participatory protections beyond the named parties; and they extend to all regulated parties upon promulgation, rather than having binding effect only upon the named parties.

33. Stewart describes the rise of "the model of interest representation" in administrative law after about 1960. Stewart, supra note 17, at 1723-90. This model rejects the ideal of agency impartiality: "[A]gency policy has become in large degree a function of bargaining and exchange with and among the competing private interests whom the agency is supposed to rule." Id. at 1760 . Independent agency officers are now allowed to participate in rulemaking absent a "clear and convincing showing" of an "unalterably closed mind." Association of Nat'l Advertisers v. FTC, 627 F.2d 1151, 1154 (D.C. Cir. 1979), cert. denied, 447 U.S. 921 (1980). Thus, the ideal of impartiality has been substantially undermined even in the agency found to be independent and impartial in Humphrey's Executor.

34. The threat of a legislative veto would seem to add some of the heat of politics to the "coldest neutrality" once required of the independent Interstate Commerce Commission. ICC v. Chicago, R.I. \& Pac. Ry., 218 U.S. 88, 102 (1910).

35. The reduced requirement of impartiality is seen most clearly in the case of commissioners of independent agencies, who now often exercise bath rulemaking and adjudicatory authority. This Note points out the decline of the ideal of impartiality with respect to these officers, and advocates that they be removable by the President. For lesser officials, such as administrative law judges (ALJ's), the general movement towards separation and insulation of functions within an agency indicates the continuing importance of impartiality for purely adjudicatory officials. See W. GeLLHORN, C. BYSE, \& P. Strauss, Administrative Law: Cases and Comments 752-59 (7th ed. 1979) (rise in stature of ALJ's). The need to protect adjudication remains separate from the point that impartiality today 
No other ideals that require independence are evident. ${ }^{38}$ Given the apparent impossibility of achieving even close approximations to neutral expertise and impartiality, and given the normative reasons favoring accountability over the two ideals, the need for independence no longer justifies placement of agencies outside of the executive branch.

\section{Convergence of Modes of Functioning}

Any original distinction between executive and independent agencies based on their modes of function ${ }^{37}$ has disappeared in the half-century since Humphrey's Executor. Both then and later, the functional ${ }^{38}$ basis for independence evidently depended on the mode of agency action: Apolitical adjudication was independent, while more political actions such as the making of substantive rules ${ }^{39}$ remained in the executive branch. ${ }^{40}$

does not distinguish independent agencies in any way from executive agencies.

36. The text refers to the lack of justifications of independence for its own sake. For discussion of arguments for independence based on opposition to presidential power, see infra text accompanying notes $108-119$.

37. "Mode of function" is a particular sort of activity of government, including rulemaking, adjudicating, licensing, ratemaking, and investigating. For most purposes, the first four of the above can be analyzed in terms of the extremes of political rulemaking and apolitical adjudication. But see infra note 119 (discussion of ratemaking power of the Federal Reserve Board).

38. Distinguishing among three meanings of "function" clarifies the relationship between formalism and functionalism. The first meaning is the overall goal, as in "the primary 'function' of separation of powers is to prevent tyranny." See Buckley v. Valeo, 424 U.S. 1, 121 (1975) (per curiam); ThE FEDERALIST No. 47, at 301 (J. Madison) (C. Rossiter ed. 1961). Functionalism and formalism share this goal. Functionalism seeks directly to achieve this and subsidiary goals, such as the assurance of impartiality and expertise, through balancing of practical considerations. Formalism, in contrast, attempts to prevent tyranny by preventing any branch from overstepping the restraints provided in the constitutional text. A second meaning of function refers to the three "functions" of government, as exercised by the legislative, executive, and judicial branches. The three functions do not correspond precisely with the three branches; the President's veto, for instance, although exercised by the executive branch, is part of the legislative function. Formalism posits that each branch should act only in pursuit of its named function, except when the Constitution specifically indicates an exception. See supra note 7. Functionalism allows exceptions in addition to those explicitly listed in the Constitution when pragmatic considerations so dictate. The third meaning of "function" refers to the various modes of function by which government operates, such as rulemaking and adjudication. Functionalism has used the mode of function of adjudication as a criterion for justifying independence: Independence is one way to foster agency impartiality and expertise and to avoid possibly excessive concentration of power in the President's hands.

39. The FTC was granted the power to issue rules of practice and procedure by the Federal Trade Commission Act, ch. 311, § 6, 38 Stat. 717, 721 (1914) (codified at 15 U.S.C. $\S \S 41,46$ (1982)). The FTC did not promulgate its first substantive rule until 1971. See National Petroleum Refiners Ass'n. v. FTC, 482 F.2d 672 (D.G. Cir. 1973) (upholding FTC substantive rulemaking authority), cert. denied, 415 U.S. 951 (1974).

40. Such a functional distinction is supported by Wiener v. United States, 357 U.S. 349 (1958), the only presidential removal case the Supreme Court has decided since Humphrey's Executor. In reaffirming the latter case, the Court in Wiener stated the functional test: "[T]he most reliable factor for drawing an inference regarding the President's power of removal in our case is the nature of the function that Congress vested in the War Claims Commission." Id. at 353. In its holding, the Court made clear the nature of that function, rejecting "the claim that the President could remove a member of an adjudicatory body like the War Claims Commission." Id. at 356 (emphasis added). See also Consumer Energy Council v. FERC, 673 F.2d 425, 472 (D.C. Cir. 1982) ("The fundamental justification for making agencies independent is that since they exercise adjudicatory powers requiring 
Such a distinction was imperfect in 1935. Contrary to the Court's weak argument in Humphrey's Executor, the FTC itself had clearly executive functions in $1935 .{ }^{11} \mathrm{Also}$, at that time, independent agencies such as the Interstate Commerce Commission made extensive substantive rules. ${ }^{43}$

Even assuming the distinction was valid in the earlier period, there has been a dramatic shift to agency action through rulemaking during the last twenty-five years, ${ }^{43}$ a shift in which independent agencies have participated fully. ${ }^{44}$ Executive agencies also adjudicate extensively; ${ }^{45}$ the Social Security Administration, an executive branch agency, "operates the largest system of administrative adjudication in the Western world." 48 The same procedural safeguards that ensure the impartiality of executive branch adjudications $\mathrm{s}^{47}$ can apply to independent agencies-further "independence" is not necessary. ${ }^{48}$ Thus, contrary to the assertion of Humphrey's Executor, there is no distinctive character of independent agencies; they act in the same ways as do executive agencies. ${ }^{49}$

impartial expertise, political interference is undesirable.") (emphasis added), affd sub nom. Process Gas Consumers Group v. Consumer Energy Council, 103 S. Ct. 3556 (1983).

41. The Court asserted that the FTC acted "in part quasi-legislatively and in part quasijudicially," 295 U.S. at 628 , but was "neither political nor executive," $i d$. at 624 . In describing the FTC's quasi-legislative duties, however, the Court could point only to the FTC's "making investigations and reports thereon for the information of Congress under $\$ 6$, in aid of the legislative power." Id. at 628. As the Court recognized in a footnote, however, the FTC in 1935 also had the power to investigate and make reports thereon for the information of the President. Id. at $628 \mathrm{n}$.*. The Court nevertheless maintained that this latter invèstigative power was "so obviously collateral to the main design of the act as not to detract from the force of this general statement" about the quasi-judicial and quasi-legislative nature of the FTC. Id. In light of the identical dual grant of investigative power, there was nothing in the functions performed by the FTC in 1935 which made it any more a quasilegislative than a quasi-executive agency.

42. See, e.g., St. Louis, I.M. \& S. Ry. v. Taylor, 210 U.S. 281 (1908) (upholding setting of standard by ICC under Safety Appliance Act of 1903, ch. 196, § 5, 27 Stat. 531); Delaware \& Hudson Co. v. United States, 5 F.2d 831 (S.D.N.Y. 1925) (upholding ICC rules relating to installation of automatic train-stop and other safety devices under Transportation Act of 1920, ch. 91, § 441, 41 Stat. 498-99); see also R. Cushman, The InDependent Regulatory Commissions 428 (1941) (importance of voluminous safety and other regulations of ICG).

43. Antonin Scalia has described "what is perhaps the most notable development in federal government administration during the past two decades . . . the constant and accelerating flight away from individualized, adjudicatory proceedings to generalized disposition through rulemaking." Scalia, Vermont Yankee: The APA, the D.C. Circuit, and the Supreme Court, 1978 SUP. CT. REv. 345, 376.

44. Id. at 376-82, and cases cited at 382 n.156.

45. Consumer Energy Council v. FERC, 673 F.2d 425, 472 n.198 ("Executive agencies perform the same adjudicatory and rulemaking functions as do independent agencies."), aff'd sub nom. Process Gas Consumers Group v. Consumer Energy Council, 103 S. Ct. 3556 (1983).

46. J. Mashaw, Bureaucratic Justice 18 (1983).

47. The Supreme Court has upheld executive agency adjudications against due process challenges. In holding that an evidentiary hearing is not required prior to the termination of Social Security disability benefits, the Court said: "[T]he prescribed procedures not only provide the claimant with an effective process for asserting his claim prior to any administrative action, but also assure a right to an evidentiary hearing, as well as to subsequent judicial review, before the denial of his claim becomes final." Mathews v. Eldridge, 424 U.S. 319, 349 (1976).

48. See infra note 116.

49. This is not to go so far as Strauss, supra note 3, at 596, who denies any significant difference in presidential relations with executive and independent agencies. That both sorts of agencies use the 


\section{B. Functional Arguments Favoring Incorporation}

A functional analysis of incorporation today must weigh the diminished importance of expertise and impartiality against arguments favoring incorporation. In addition to the formalist arguments for incorporation discussed below, ${ }^{\text {so }}$ the functionalist arguments for incorporation include the executive's ability to coordinate regulatory policy and the new importance, given the invalidation of the legislative veto, of assuring agency accountability.

\section{Coordinating Agency Policy}

The present need for coordination of agency policy supports a greater presidential role in regulation, ${ }^{\mathrm{s}}$ and may be persuasive even to many of those generally skeptical of presidential power. ${ }^{52}$ The history of creating a new agency to address each new national issue has led to a plethora of single-issue agencies, each narrowly focused on the demands of its own issue area. With the enormous increase since the Great Society in the amount of regulation, ${ }^{\text {ss }}$ the costs of inconsistent or duplicative regulation have risen..$^{54}$

The President, elected nationally, ${ }^{\mathbf{5 5}}$ charged with executing all federal laws, and accountable for the sum-total of executive action, has a unique potential to balance and coordinate agency action. ${ }^{56}$ Through the use of

same modes of function, such as rulemaking and adjudication, leaves open the possibility that the President's powers to remove, to issue binding executive orders, and to supervise agency enforcement result, in general, in greater presidential control over executive agencies.

50. See infra Part III.

51. See, e.g., ABA Comm'n on Law \& the Economy, Federal Regulation: Roads to Reform (1979) [hereinafter cited as RoADs to ReFORM]; Bernstein, The Presidential Role in Administrative Rulemaking: Improving Policy Directives: One Vote for Not Tying the President's Hands, 57 Tul. L. Rev. 818 (1982); Cutler \& Johnson, Regulation and the Political Process, 84 YALE L.J. 1395 (1975).

52. See infra text accompanying notes 108-119 (responses to fears of excessive presidential power).

53. For the amount of new regulatory legislation, see supra note 32 . While it is notoriously difficult to calculate the total costs of regulation, estimates reviewed by one study, not including benefits, ranged from $\$ 31$ billion to $\$ 78$ billion, in 1977 dollars, for each year between 1975 and 1980 . $R$. LrTAN \& W. NoRdhaUs, supra note 32, at 25.

54. One study detailed sixteen different agencies responsible for often-overlapping aspects of energy policy. RoADS to REFORM, supra note 51, at 71-72.

The frequency of overlapping jurisdiction makes likely the occurrence of "cumulatively excessive" regulation, in which multiple agencies issue rules that are cost-justified in isolation but cumulatively excessive in impact; the likelihood of cumulatively excessive regulation was an important spur to passage of the Paperwork Reduction Act of 1980, Pub. L. No. 96-511, § 2(a), 94 Stat. 2812 (codified at 44 U.S.C. $\S \S 2904,2905,3501$ to 3520 (1982)); S. REP. No. 630, 96th Cong., 2d Sess. 3, reprinted in 1980 U.S. CoDE CoNG. \& AD. News 6241, 6243.

55. The unmatched intensity of political discourse that surrounds modern presidential elections is an additional reason to believe the President is uniquely accountable to the popular will.

56. See INS v. Chadha, 462 U.S. 919, 948 (1983) (quoting Myers v. United States, 272 U.S. 52, 123 (1926)) (President in some respects more representative than legislature). 
executive orders, recent Presidents have attempted to reduce these regulatory costs. ${ }^{57}$ Such orders have been necessarily incomplete because of the relatively limited executive authority over independent agencies. ${ }^{58}$ Given the extensive role of independent agencies in modern regulation, the need for coordination supports incorporation.

\section{Accountability and Agency Independence}

Given the decline in the ideals of expertise and impartiality, accountability to the political branches has become an increasingly important basis for the legitimacy of agency action. Accountability is antithetical to the idea of independence ${ }^{58}$-accountability is to some other branch, to Congress or the Executive. ${ }^{60}$ After the invalidation of the legislative veto in Chadha ${ }^{61}$ Congress faces increased difficulties in monitoring and controlling specific agency actions. Indeed, both Congress ${ }^{62}$ and its supporter in Chadha, Justice White, ${ }^{\text {b3 }}$ have explicitly stated that the legislative veto was essential to effective accountability to Congress. ${ }^{64}$

In comparison, the President has certain advantages. The powers to

57. Presidents Reagan, Carter, and Ford all issued executive orders calling for cost/benefit analysis of proposed agency regulations. Exec. Order No. 12,291, 3 C.F.R. $§ 127$ (1982); Exec. Order No. 12,044, 3 C.F.R. § 152 (1979); Exec. Order No. 11,821, 3A C.F.R. § 203 (1974).

58. See infra text accompanying notes 97-99. Some, but not all, independent agencies acquiesced to presidential requests to participate in the cost/benefit reviews. Strauss, supra note 3, at 593 n.78.

59. "Indeed, it is ironic that Congressional amici attempt to place great significance on the Commission's independence and on the need for having a politically accountable check on the agency's decision. The fundamental justification for making agencies independent is that . . political interference is undesirable." Consumer Energy Council v. FERC, 673 F.2d 425, 472 (D.C. Cir. 1982), affd sub nom. Process Gas Consumers Group v. Consumer Energy Council, 103 S. Ct. 3556 (1983). See also Brief of Amici Curiae United States Senate and the Speaker of the United States House of Representatives at 45, Consumer Energy Council, supra, ("special appropriateness" of "democratic accountability" to Congress in agency rulemaking affecting matters historically regulated by states) [hereinafter cited as Congressional Amici Brief].

60. In practice, such accountability is always shared by the two branches, and their relative strength varies with the intricate eddies of Washington politics. Furthermore, as also suggested by Strauss, supra note 3 , at 586 n.46, Presidents may have relatively great ability to slow or halt agency enforcement or other action. In contrast, increased presidential power to hold agencies accountable may become more important during an activist administration, where the President seeks to coordinate agency initiatives.

61. See infra text accompanying notes 81-93.

62. See supra note 59 .

63. Justice White described the legislative veto as "an important if not indispensable political invention that .... assures the accountability of independent regulatory agencies . . . " INS v. Chadha, 462 U.S. at 972 (White, J., dissenting). He elaborated upon this point in his dissent to the case striking down the legislative veto as applied to independent agencies, where he stated that invalidation of the legislative veto "merely guarantees that the independent agencies, once created, for all practical purposes are a fourth branch of government not subject to the direct control of either Congress or the executive branch. I cannot believe the Constitution commands such a result." Process Gas Consumers Group v. Consumer Energy Council, 103 S. Ct. 3556, 3558 (1983). White's argument for accountability, once the unconstitutionality of the legislative veto is established, becomes an argument for accountability to the only remaining branch-to the President.

64. See supra note 59; see also Chadha, 462 U.S. at 973 n.10 (White, J, dissenting) (Justice White's analysis of inadequacies of alternatives to legislative veto). 
appoint, to remove, and to issue binding executive orders ${ }^{65}$ can affect agency action without resort to the lengthy and often blunt process of legislation. Recent history offers several examples of popular sentiment apparently influencing the President, who in turn induced agencies to conform to that sentiment-the very model of accountability. ${ }^{66}$ In the aftermath of Chadha, the President appears to have significant advantages over the Congress in assuring agency accountability. As with coordination, the need for accountability now supports incorporation.

\section{Formalism AND Agency IndePENDENCE}

Not only are the specific functional bases for independence now undermined, but the entire functionalist approach to separation of powers, first accepted by the courts in the mid-thirties, is now being sharply limited. In recent cases, the Supreme Court has espoused a new formalism that rejects the functionalist tenets of flexibility, practicality, and reluctance to enforce the doctrine of separation of powers based on isolated parts of the Constitution. ${ }^{87}$ The historical link between functionalism and agency independence, given the decline of the former, makes the latter appear increasingly anomalous. In the absence of some new basis for independence, the anomaly calls for the incorporation advocated by this Note.

Recent cases have returned toward the formalist rule in Myers that branches may blend their powers-may share in the direction of particular government actions-only where affirmatively permitted by the Constitution. A formal reading of the constitutional text results in tripartitism-permission for only the three branches created by the Constitution. Language from several recent cases corroborates such a return to tripartitism.

\section{A. Buckley v. Valeo}

In Buckley v. Valeo, ${ }^{68}$ the Supreme Court held unconstitutional the appointment procedure of the independent Federal Election Commission (FEC), under which Congress nominated four of the six voting Commis-

65. See infra text accompanying notes 94-99 (effects of incorporation on removal power and power to issue binding executive orders).

66. Examples include the departures of Anne Burford from the Environmental Protection Agency and James Watt from the Department of the Interior. Policies in both agencies moderated after the change in agency head. See N.Y. Times, May 20, 1984, $\$ 1$, at 30, col. 3 (new EPA Administrator, William Ruckelshaus, "widely credited with restoring . . . credibility" to the agency); N.Y. Times, Feb. 21, 1984, at B8, col. 3 (large changes at Interior under new Secretary William Clark). Another example concerns the Social Security Administration. In response to intense political criticism, President Reagan ordered SSA to halt terminations of disability recipients. N.Y. Times, Mar. 24, 1984, at A1, col. 6.

67. See supra text accompanying notes 16-22.

68. 424 U.S. 1 (1975) (per curiam). 
sioners. ${ }^{89}$ In forbidding Congress to nominate officials exercising powers beyond the "legislative" powers Congress could delegate to its own committees, ${ }^{70}$ the Court gave an expressly formalist interpretation of the appointments clause. ${ }^{71}$ Saying that the three branches must remain "largely separate," ${ }^{\prime 72}$ the Court held that a statute could not justify Congress' sharing the appointment power with the President in a way not permitted by the Constitution. ${ }^{\text {73 }}$

In conformance with the Myers rule against blending, ${ }^{34}$ the Court stated in strong terms the exclusive power of the executive branch to direct all enforcements in the courts made in the name of the United States. ${ }^{75}$ The Court thereby threw into doubt the constitutionality of various statutes under which the executive branch shares the enforcement power with certain independent agencies. ${ }^{76}$

Most importantly for the future status of independent agencies, the Court for the first time gave a substantive definition to "officer of the United States." ${ }^{\text {"77 }}$ In striking down the statute's scheme for the appoint-

69. Under the Federal Election Campaign Act Amendments of 1974, Pub. L. No. 93-443, $\S$ 310(a), 88 Stat. 1263, 1280-81 (codified as amended at 2 U.S.C. $\$ 437$ c (1982)), the FEC had six voting members, two appointed by the President, two by the President pro tempore of the Senate, and two by the Speaker of the House of Representatives, all six of whom were subject to confirmation by a majority vote of both houses of Congress.

70. 424 U.S. at 137.

71. The Supreme Court noted that the Court of Appeals had characterized the argument based on the appointments clause, U.S. CoNST. art. II, § 2, cl. 2, as "strikingly syllogistic," 424 U.S at 119, that is, as formalist. Nonetheless, the Supreme Court relied on that argument to hold the Act unconstitutional. Id. at $140-41$.

72. "[T]he intent of the Framers [was] that the powers of the three great branches of the National Government be largely separate from one another." Id. at 120. The further suggestion in Buckley that the branches need not be "hermetically sealed," id. at 121, was later interpreted to mean that each branch should "as nearly as possible . . . confine itself to its [constitutionally] assigned responsibility." Chadha, 462 U.S. at 951 (cmphasis added).

73. 424 U.S. at $140-41$.

74. See supra note 7.

75. Concerning litigation in the courts of the United States, "it is clear that all such suits, so far as the interests of the United States are concerned, are subject to the direction, and within the control of, the Attorney-General." 424 U.S. at 139 (quoting Confiscation Cases, 74 U.S. (7 Wall.) 454, 458-59 (1869)). The Court also said:

The Commission's enforcement power, exemplified by its discretionary power to seek judicial relief, is authority that cannot possibly be regarded as merely in aid of the legislative function of Congress. A lawsuit is the ultimate remedy for a breach of the law, and it is to the President, and not to the Congress, that the Constitution entrusts the responsibility to 'take Care that the Laws be faithfully executed.' Art. II, $\S 3$.

424 U.S. at 138.

76. See infra text accompanying notes 100-102 (enforcement power after incorporation).

77. The definition of "officer" derives from the appointments clause, U.S. CoNSr. art. II, $\S 2, \mathrm{cl}$. 2, which provides:

[The President] shall appoint . . . all other Officers of the United States, whose Appointments are not herein otherwise provided for, and which shall be established by Law: but the Congress may by Law vest the Appointment of such inferior Officers, as they think proper, in the President alone, in the Courts of Law, or in the Heads of Departments.

Historically, "officer" and "inferior officer" were distinguished by the method of appointment; someone nominated by the President and confirmed by the Senate was an "officer," while someone ap- 
ment of FEC Commissioners by Congress, the Court held as a matter of constitutional law that the Commissioners exercised "significant authority pursuant to the laws of the United States," and were thus "officers."

This new definition of "officer", when combined with the demise of the functional distinction between executive and independent agencies, appears to confirm the President's removal power over independent agency heads. Myers and Humphrey's Executor agreed on the President's illimitable removal power over executive officers, although Humphrey's Executor exempted the Federal Trade Commissioner on functionalist grounds. As discussed earlier ${ }^{79}$ however, there appears to be no basis today for a functional distinction between executive and independent agencies. The lack of a distinction thus leads to the conclusion that all agency heads are executive officers, and thereby subject to the President's removal power. The import of Buckley is that Congress loses any previous ability to define agency heads as "inferior officers" or "employees"; the constitutional holding that heads of agencies are "officers" eliminates the escape hatch that would otherwise have been available. ${ }^{80}$

\section{B. INS v. Chadha}

The new formalism reached its fullest development in INS $v$. Chadha ${ }^{81}$ which held the legislative veto unconstitutional. Three factors support both a formalist interpretation of Chadha, and consequent incor-

\footnotetext{
pointed by the President, the courts, or a department head, without Senate confirmation, was an "inferior officer." Lesser governmental officials were "employees." See Burkoff, Appointment and Removal Power under the Federal Constitution: The Impact of Buckley v. Valeo, 22 WAYNE L. REv. 1335, 1342-57 (1976) (history of case law under appointments clause). The boundaries among "officer," "inferior officer," and "employee" remain muddy. See id. at 1357-69 (Buckley's effect on meaning of "officer"). One sensible resolution would be to apply a general rule of categorization according to the method of appointment, while recognizing that an agency head, due to the importance of the office and the special role in aiding the President in execution of the laws, must be an "officer." But see infra note 80 (proposing exceptions to such a rule).

78. 424 U.S. at 126.

79. See supra text accompanying notes 23-36 (undermining of functionalist distinctions).

80. Absent the substantive definition of officer, Congress would have had the power, for instance, to insulate an agency head from removal by lodging the responsibility for appointment with the head of some department. Such congressional power to change the formal characteristics of an office suggests that the courts, if they are to maintain the substantive definition, will not in all cases be able to categorize a non-agency head as "officer" or "inferior officer" based simply on the manner of appointment.

81. 462 U.S. 919 (1983).

An earlier theory arguing for the expansion of presidential control over independent agencies was proposed by Bruff, Presidential Power and Administrative Rulemaking, 88 YalE L.J. 451 (1979). This Note agrees with Bruff in some respects, especially with his policy arguments for expanded presidential control of independent agencies, id. at 454-56, 461-63, and his assertion that the distinction between executive and independent agencies "is belied by practice," id. at 480 . However, writing before Chadha and Northern Pipeline, Bruff could not fully take into account the emerging formalism of the Burger Court. The recent cases support more than Bruff's limited claims to presidential control of independent agencies.
} 
poration of independent agencies into the executive branch. First, the holding of unconstitutionality rested squarely on a formalist reading of the presentment and bicameralism clauses, ${ }^{82}$ indicating a rejection, without even an assessment of practical desirability, ${ }^{83}$ of an institutional arrangement not specified by the Constitution. Independent agencies, even if functionally desirable, similarly lack firm anchor in the constitutional text. ${ }^{84}$ Second, the opinion indicates that the formalist attitude extends to tripartitism. The Court opened its discussion of separation of powers by stating that the Constitution divides the government's powers into "three defined categories."85 The majority's acceptance of tripartitism-its rejection of

82. To invalidate the legislative veto, the Court relied on the presentment clauses, U.S. ConST. art. I, $\S 7$, cls. 2, 3, which guarantee the presidential veto power, and the bicameral requirement for passage of a law, U.S. CoNST art. I, $\S \S 1 \& 7$, cl. 2. The Court's awareness of its formalist reliance on text is revealed by its mention, 462 U.S. at 946 , of the similarity of the reliance in Buckley on the text of the appointments clause.

83. The Court conceded the functionalist concern that adherence to constitutional text can "impose burdens on governmental processes that often seem clumsy, inefficient, even unworkable . . .." 462 U.S. at 959 . Nonetheless, the majority affirmed its belief in conformance to the text: "With all the obvious flaws of delay, untidiness, and potential for abuse, we have not yet found a better way to preserve freedom than by making the exercise of power subject to the carefully crafted restraints spelled out in the Constitution." Id.

In another example of such a rejection, a plurality used a formalist interpretation of the Article III "judicial power" to find unconstitutional a congressional grant of jurisdiction to the bankruptcy courts. Northern Pipeline Constr. Co. v. Marathon Pipe Line Co., 458 U.S. 50 (1982) (plurality opinion). The opinion relied exclusively on doctrine drawn from Article III, rather than on any functionalist evaluation of the statute's practical desirability.

84. But see Strauss, supra note 3, at 640 . Strauss proposes that agencies not "be regarded as having been placed in one or another branch but rather . . . as subordinate bodies subject to the controls of all three." In addition to conflicting with the other reasons given in this Note for expanded presidential control, Strauss's position would apparently permit Congress to set limits on the ability of the President to remove officers intimately linked to presidential policies, such as the Secretary of State or the Attorney-General. Such limits would strike at the core of the President's duty to "take Care that the Laws be faithfully executed," as required by U.S. ConST. art. II, § 3. See Myers v. United States, 272 U.S. at 131 (parading horrible of "men who by their inefficient service under [the President], by their lack of loyalty to the service, or by their different views of policy, might make his taking care that the laws be faithfully executed most difficult or impossible").

85. "The Constitution sought to divide the delegated powers of the new federal government into three defined categories, Legislative, Executive and Judicial, to assure, as nearly as possible, that each Branch of government would confine itself to its assigned responsibility." 462 U.S. at 951 . The Court then turned to analysis of "the powers delegated to the three Branches," id. at 2784 (emphasis added), without the slightest hint that powers remain outside of those three branches. See also Northern Pipeline Constr. Co. v. Marathon Pipe Line Co., 458 U.S. at 57 (emphasis on "three distinct Branches"). Interpretation of the Court's use of "three" to mean "three and only three" is supported by its apparent reliance on the formalist rule of construction expressio unius est excludio alterius ("the expression of one thing is the exclusion of the other"). For instance, the Court suggested the rule by considering exceptions to bicameralism and then stating "congressional authority is not to be implied." Chadha, 462 U.S. at 956; see Elliott, INS v. Chadha: The Administrative Constitution, The Constitution, and The Legislative Veto, 1983 Sup. CT. REv. 125, 139-44 (discussing expressio unius). Elliott's three reasons for declaring the maxim inappropriate in constitutional interpretation do not apply to the question of the constitutionality of the fourth branch. First, Elliott says the list of specific members of a class might not have been intended as exhaustive; however, there exists no reasonable argument that the Framers intended any more than three branches. Second, Elliott points out that general permissive language may contradict the premise that the drafters intended the enumeration to be exhaustive; however, there exists no general, permissive language to support a fourth branch. Third, Elliott argues that "linguistic aids to ascertaining the intent of 'the Draftsmen' should 
any "fourth branch"-is underscored by a striking linguistic disregard for the distinction between executive and independent agencies. The majority repeatedly subsumed both executive and independent sorts of agencies under the term "administrative agency," ${ }^{\text {86 }}$ a sign of the trend, also evident in other recent cases ${ }^{87}$ toward a blurring of the executive-independent distinction. ${ }^{88}$ In marked contrast, Justice White ${ }^{88}$ and other critics of Chadha ${ }^{80}$ have scrupulously retained the distinction-in dissent. The third factor linking Chadha to incorporation is the immediate extension of Chadha to independent agencies. The Supreme Court rejected congressional claims to special control over independent agencies ${ }^{91}$ when it sum-

carry relatively little weight in interpreting the Constitution." Id. at 140 . However, granted a legitimate skepticism about our ability to comprehend the language of a clause torn from context, tripartitism would still seem to be quite firmly grounded. The theory that the Constitution creates three and only three branches relies not only on the specific clauses establishing the legislative, executive, and judicial powers, U.S. CoNST. art. I, $\S 1$; art. II, $\S 1$; art. III, $\S 1$, but also on the basic structure of the document-a fourth branch can be implied only in the face of three and only three articles that constitute the basic institutions of government.

Beginning with the overarching formalist rule that permits blending of branches only where affirmatively permitted by the Constitution, the new formalism has held, among other things: (1) that the appointments clause bars appointment procedures not listed therein, Buckley v. Valeo, 424 U.S. 1, 137 (1975) (per curiam); (2) that the presentment clauses bar legislation not in conformity with the specified presentment procedure, Chadha, 462 U.S. at 956; and (3) that the bicameralism requirements forbid legislation except as provided by the constitutional text, id. at 955-56. In this context of expressio unius, the Chadha majority's use of "three branches" thus seems strongly to suggest the interpretation "three and only three branches."

86. None of the majority's six uses of the term "administrative" showed any hint of a distinction between executive and independent agencies. 462 U.S. at 951, 953 n.16 (three times), 955 n.19, 957 n.22. The only use of "independent" in the agency context was in a description of legislative veto statutes passed by Congress. Id. at 2781 . That is, the Court recognized independent agencies only within statutes found unconstitutional by its holding.

87. Justice Brennan, writing in dissent for Justices Blackmun, Marshall, and Stevens, recently wrote: "[I]t is difficult to conceive of an expenditure for which the last governmental actor . . . is not an Executive Branch official." Valley Forge College v. Americans United for Separation of Church and State, 454 U.S. 464, 511 (1982) (Brennan, J., dissenting) (emphasis added). Justice Brennan has also used "administrative" in the inclusive sense, later used in Chief Justice Burger's opinion in Chadha, to indicate both executive and independent agencies. Northern Pipeline Constr. Co. v. Marathon Pipe Line Co., 458 U.S. 50, 67 n.18 (1982) (plurality opinion).

88. "Administrative agency" has historically been synonymous with "independent agency." See, e.g., J. LANDIS, supra note 17, at 2-3. In Humphrey's Executor v. United States, 295 U.S. 602 (1935), and Wiener v. United States, 357 U.S. 349 (1958), the only two Supreme Court removal cases since the rise of functionalism, there is no use of "administrative" for any activity within the executive branch. The Immigration and Naturalization Service, at issue in Chadha, is part of the Justice Department, a clearly executive agency.

89. Justice White insisted at every opportunity-ten times-on distinguishing executive from independent agencies. 462 U.S. at 972, 980, 984, 985, 986, 987, 989, 998, 999, 1002.

90. Note the distinction in one title: Levitas \& Brand, Congressional Review of Executive and Agency Actions After Chadha: "The Son of Legislative Veto" Lives On, 72 GEo. L.J. 801 (1984); see also id. at 805 (discussing actions of "executive and independent agencies").

91. "FERC performs only those functions as assigned to it by Congress; it derives no independent authority from the Constitution, and separation of powers principles do not apply to it." Congressional Amici Brief, supra note 59, at 40-41 (emphasis added). 
marily affirmed two cases ${ }^{92}$ invalidating legislative vetos of independent agency action. ${ }^{93}$

\section{Ghanges in Agency Independence}

Under either formalism or functionalism, the central tension is between the power of the President to execute the laws and the power of Congress to establish and shape agencies by statute. With respect to this tension, the developments described in this Note have little or no effect upon the President's power over the agencies already in the executive branch. The "incorporation" of independent agencies is essentially a matter of specifying the ways now-independent agencies will become the same as nowexecutive agencies. The implications of incorporation are similar, but not necessarily identical, whether incorporation is based on either formalist or functionalist arguments, or both.

\section{A. Implications of Formalism for Agency Independence}

The new formalism implies four conclusions concerning incorporation: (1) an expansion of the President's removal power to independent agencies; (2) a similar expansion of the power to issue binding executive orders; (3) possibly, an expansion of the President's powers to coordinate enforcement in the courts; and (4) the permissibility of purely investigatory agencies outside of the executive branch.

Since Myers, the President's power to remove executive officers has been secure. ${ }^{94}$ With incorporation of independent agencies into the executive branch, all agency "officers" become subject to that removal power. ${ }^{95}$

92. Process Gas Consumers Group v. Consumer Energy Council, 103 S. Ct. 3556 (1983), affg Consumer Energy Council v. FERC, 673 F.2d 425 (D.C. Cir. 1982); United States Senate v. FTC, 103 S. Ct. 3556 (1983), affg Consumers Union v. FTC, 691 F.2d 575 (D.C. Cir. 1982) (en banc). Contrast the seeming identity of independent and executive agencies in the two cases with the insistence of the Court in Humphrey's Executor that the duties of the FTC were "neither political nor executive." 295 U.S. at 624.

93. Still unanalyzed are at least two aspects of the new formalism. First, the new formalism operates on law, not politics. The majority in Chadha believed that formalism sufficiently answered the main thrust of Justice White's dissent-that the political power of the modern presidency requires the check of the legislative veto. Second, and relatedly, the new formalism has not yet justified itself. The stated goal of separation of powers is to prevent the possibility of tyranny. See supra note 38. Nothing in that goal, or in the opinions of the Court thus far, explains why the Court now stresses formalism, rather than an updated functionalism.

One might speculate that the Court has lost faith in its ability to discover and guide political checks and balances. Or, the Court's earlier reliance on functionalism might have threatened to undermine the role of the Court as expounder of the Constitution. Whatever the rationale, the new formalism is current law, and law which by its own logic leaves no place for independent agencies.

94. Courts have continued to uphold the President's power to remove executive officers. E.g., Martin v. Tobin, 451 F.2d 1335, 1336 (9th Cir. 1971); Martin v. Reagan, 525 F.Supp. 110, 113 (D. Mass. 1981).

95. See supra text accompanying notes 79-80. 
It is important to note, however, another rule approved in Myers, that Congress retains the power to prescribe by statute the grounds for removal of "inferior officers" and "employees." While the exact line between "officers" and these latter officials remains unclear, Buckley appears to hold that agency heads are "officers." Incorporation would thus mean that all agency heads are removable.

A second implication of incorporation involves the power of the President to issue executive orders binding on now-independent agencies. Presidents have traditionally refrained from imposing executive orders on independent agencies in the absence of statutory permission, ${ }^{97}$ although they have asserted the right to do so. ${ }^{88}$ The strengthened tripartitism of the new formalism would assure the executive the power to bind both nowindependent and now-executive agencies equally. ${ }^{.9}$

A possible third implication of incorporation concerns the scope of the President's oversight of enforcement of civil suits in the name of the United States. The Court in Buckley stated in very strong language that the responsibility for all such suits is entrusted to the President, and hence

96. Myers upheld the exclusive removal power of the President over a first-class postmaster appointed by the President. The broad executive power of the President, to be effective, required the power to remove subordinates when they could no longer execute his orders. In addition, the power of appointment by the President carried with it, by necessary implication, the power of removal. 272 U.S. at 117-19. Neither principle applied to presidential removal of an inferior officer where the appointment power was lodged in the head of a department. Id. at 127 (citing United States v. Perkins, 116 U.S. 483,485 (1886)). Congress thus apparently retains authority to prescribe grounds of removal for inferior officers appointed by heads of departments, and a fortiori for employees, who are even more distant from the President.

97. For instance, Presidents Reagan, Garter, and Ford all refrained from including independent agencies within the scope of executive orders concerned with cost/benefit analysis of proposed regulations. Exec. Order No. 12,291, 3 C.F.R. § 127 (1982); Exec. Order No. 12,044, 3 C.F.R. § 152 (1979); Exec. Order No. 11,821, 3A C.F.R. § 203 (1974); see also supra note 1 (quoting President Reagan's executive order). Such restraint probably has occurred in large part out of presidential reluctance to fight Congress on the issue. See Letter from Senate Comm. on Governmental Affairs to President Carter (Dec. 16, 1977) (concerning proposed Executive Order on Federal Regulation), reprinted in Role of $O M B$ in Regulation: Hearing Before the Subcomm. on Oversight and Investigations of the House Comm. on Energy and Commerce, 97th Cong., 1st Sess. 170 (1981) [hereinafter cited as Hearing]. This letter consisted of a detailed legal argument that the proposed extension of the executive order to independent agencies was outside presidential authority. Incorporation of independent agencies into the executive branch would eliminate the legal basis for such congressional opposition and dramatically reduce the political costs for the President of extending executive orders to independent agencies.

98. See Office of Legal Counsel, Memorandum on Proposed Executive Order on Federal Regulation 7, reprinted in Hearing, supra note 97, at 158 ("[U]nder the best view of the law" the proposed executive order, eventually issued as Exec. Order No. 12,291, 3 C.F.R. $§ 127$ (1982), "can be imposed on the independent agencies").

99. While this Note concludes that the President should have the power to issue executive orders equally binding on all agencies, it makes no special assumption about the scope of that power. Executive orders have their effect within frameworks established by statutes; the President's power to execute the laws extends only to the direction of policy within statutorily permissible limits. Youngstown Sheet \& Tube Co. v. Sawyer, 343 U.S. 579, 587 (1952) ("[T]he President's power to see that the laws are faithfully executed refutes the idea that he is to be a lawmaker."), quoted in INS v. Chadha, 462 U.S. at 953 n.16. 
is within the control of his agent, the Attorney-General. ${ }^{100}$ Various statutes now exist that authorize independent agency enforcement outside the control of the Attorney-General. ${ }^{101}$ Those statutes may well be unconstitutional attempts by Congress to usurp a power committed to the President's control. ${ }^{102}$

A fourth implication of incorporation concerns the status of purely investigatory agencies, such as the United States Commission on Civil Rights. ${ }^{103}$ Buckley made clear that Congress may delegate to an agency, independent of the presidential power to appoint or remove, the powers that it could delegate to one of its own committees. ${ }^{104}$ Congress can delegate the power to conduct investigations. ${ }^{105}$ Therefore, even after incorporation, Congress could create purely investigatory agencies independent of the executive branch. ${ }^{108}$

100. See supra note 75 .

101. See Senate Comm. on Governmental affairs, 5 Study on Federal Regulation, S. Doc. No. 811, 95th Cong., 1st Sess. 54-67 (1977) (description of supervision by the Justice Department of independent agency enforcement) [hereinafter cited as STUDY ON Federal Regulation]. This study summarized the enforcement powers of independent agencies:

[T] hree independent regulatory commissions-FERC, FTC, and SEG-have complete or near complete authority to initiate and conduct lawsuits independent of the Justice Department; five others-CFTC, CPSC, FMC, FRB, and ICC-have only partial or doubtful authority; and the remaining agencies (CAB, FCC, and NRC) may not sue in their own name without the approval of the Attorney General.

Id. at 62. The Civil Aeronautics Board has since been disbanded. See supra note 1. Many of the other relevant provisions remain in effect. See, e.g., 15 U.S.C. § 56(a) (1982) (enforcement power of the FTC); id. $\$ \S 77 \mathrm{t}, 78 \mathrm{u}(\mathrm{c}), 79 \mathrm{r}(\mathrm{f})-(\mathrm{g}), 80 \mathrm{a}-35,80 \mathrm{a}-41$ (c), 80b-9(c) (enforcement powers of the SEC).

102. It is difficult to predict accurately whether the enforcement power within the executive branch, after incorporation, would have to be centralized under the control of the Attorney General. The congressional power under the necessary and proper clause, U.S. CoNST. art. I, $\S 8$, cl. 18, to establish and shape agency offices is subject to the limiting power of the courts to say what the law is, and more particularly to say what the constitutional imperatives within the executive branch are. The sweeping language in Buckley, see supra note 75, suggests a rather strict limit on congressional power to authorize agency enforcement outside of the discretion of the Attorney General.

Judges, even prior to the emergence of the new formalism, strained to read apparent congressional grants of enforcement powers to agencies so as to eliminate such grants. See ICC v. Southern Ry., 543 F.2d 534, 536 (5th Cir. 1976) (holding no agency enforcement power); FTC v. Guignon, 390 F.2d 323, 326 (8th Cir. 1968) (same); see also StUdy on Federal Regulation, supta note 101, at 57-62 (review of agency enforcement powers).

103. After the most extensive recent controversy concerning the President's removal power, the independence of the Commission was confirmed by the United States Commission on Civil Rights Act of 1983, Pub. L. No. 98-183, 97 Stat. 1301 (codified at 42 U.S.C.A. $\$ 1975$ (West Supp. 1984)). For a history of the controversy, see 39 Cong. Q. Almansc 292-95 (1984).

As another example, transferral out of the General Accounting Office of the Personnel Appeals Board, which adjudicates Civil Service terminations, may make the GAO exclusively investigatory, and hence eligible for independence. See 31 U.S.C. $\$ 751$ (1982) (provisions for Personnel Appeals Board). Such investigatory agencies would then be seen as legislative agencies, resembling, for instance, the Congressional Research Service.

104. 424 U.S. 1, 137 (1975) (per curiam).

105. Id. at $137-38$.

106. The argument here establishes only that Congress may create an investigatory agency that is wholly the creature of Congress. The current Commission on Givil Rights is appointed in part by Congress and in part by the President. 42 U.S.C.A. $\$ 1975$ (b) (West Supp. 1984). Such a blending of the two branches would seem impermissible under the new formalism. 


\section{B. Implications of Functionalism for Agency Independence}

The functional analysis given above ${ }^{102}$ took the opinion in Humphrey's Executor at face value. This analysis assumed the basis of the holding to be that expertise and impartiality justified independence, and that the demise of those ideals has therefore left independence without any rationale. These functional arguments for incorporation lead to some, but not necessarily all, of the implications of formalism. The removal power and power to issue binding executive orders are exactly the means of achieving the accountability and coordination that would lead a functionalist to accept incorporation. Allowing investigatory agencies in both the legislative and executive branches would mesh with a belief in the need for vigilance in checks and balances. Acceptance of centralization of the enforcement power would depend on an empirical judgment of the practical effects.

A different reading of Humphrey's Executor, however, would see the opinion instead as enforcing a check on presidential power. ${ }^{108}$ This more political reading, which sees agency independence as a limit on the potentially tyrannous imperial presidency, ${ }^{109}$ could lead one to reject incorporation despite the functionalist (and possibly formalist ${ }^{110}$ ) arguments presented in this Note. This Part suggests three answers to the fear of excessive presidential power.

First, whatever danger of excessive power that now exists very probably does not involve the administrative agencies affected by incorporation. Suspicion of excessive presidential power today arises most forcefully in areas such as national security and foreign affairs. ${ }^{111}$ The dangers of such a concentration of presidential power should be addressed directly in the

107. See supra Part II.

108. As noted also by Bruff, supra note 81 , at 482 , the case was decided the same day as the strongly anti-presidential A.L.A. Schechter Poultry Corp. v. United States, 295 U.S. 495 (1935) (delegation to President under National Industrial Recovery Act unconstitutionally overbroad).

109. See A. Schlesinger, The Imperial Presidency 212 (1973) (rise of dangerous concentration of power in presidency).

110. The choice between formalism and functionalism, starkly evident in Chadha and Northern Pipeline, is in large measure a choice between rhetorics. A strong enough threat of an imperial presidency might drive a person with formalist dispositions to accept functional checks on presidential power; conversely, a perceived threat of erosion of textual guarantees might lead a person with functionalist dispositions to accept the rigidity of formalism.

111. National security and foreign affairs are areas where the secrecy and irrevocability of many actions make political accountability and reversibility of presidential action by congressional action especially difficult. See, e.g., Quint, The Separation of Powers Under Carter, 62 TEX. L. REv. 785, 837-63 (1984). Presidents have retained the power not only to act swiftly in the event of a crisis, but also, on issues purportedly impinging on national security, to create general rules with far-ranging effects. For instance, Presidents have broad discretion to use executive orders to set criteria for classification of material. Compare Exec. Order No. 12,065, § 1-4, 3 C.F.R. § 190, 193 (1979) (President Carter's Order creating general rule of automatic declassification within six years) with Exec. Order No. 12,356, § 1.4, 3 C.F.R. $§ 166,169$ (1983) (President Reagan's Order providing for classification "as long as required by national security considerations"). It is in areas subject to such sweeping discretion that concerns about excessive presidential power would seem to have the greatest force. 
law and politics of those areas, leaving the issue of incorporation to depend on the primarily domestic considerations of health, safety, and general welfare. ${ }^{112}$

Second, an array of legal checks would remain on presidential control of agency action. Existing legal constraints on presidential power over now-executive agencies would apply, after incorporation, to nowindependent agencies. The President would have no power to override properly promulgated rules within the executive branch, ${ }^{113}$ including those involving the removal power. ${ }^{114}$ Rulemaking affected by presidential contact would be subject to the usual judicial review. ${ }^{115}$ Perhaps most importantly, the inability of the President to remove "employees" such as administrative law judges, except as provided by statute, would protect the great bulk of adjudications from political intrusion. ${ }^{116}$

Third, important political checks would remain to prevent arbitrary presidential action. ${ }^{117}$ Congressional and other opponents to presidential

112. Any undesirable concentration of power that would result would be weighed against the gains from incorporation, such as heightened accountability.

113. Motor Vehicle Mfrs. Ass'n v. State Farm Mut. Auto. Ins. Co., 103 S. Ct. 2856 (1983); United States v. Nixon, 418 U.S. 683, 696 (1974).

114. Vitarelli v. Seaton, 359 U.S. 535 (1959); Service v. Dulles, 354 U.S. 363 (1957); cf. Nader v. Bork, 366 F. Supp. 104 (D.D.C. 1973) (presidential removal of Special Prosecutor held violation of Justice Department regulation permitting removal only upon finding of extraordinary impropriety).

115. Courts would hold such rulemaking to the usual standard, generally whether the agency action was arbitrary or capricious. 5 U.S.C. $§ 706$ (A) (1982); see Sierra Club v. Costle, 657 F.2d 298, 407-08 (D.C. Cir. 1981) (White House contacts, including presidential ones, need not be in record of informal rulemaking that has substantial factual support on the record). There remains considerable uncertainty concerning the ways in which the President is exempt from restrictions on ex parte contacts. See Verkuil, Jawboning Administrative Agencies: Ex Parte Contacts by the White House, 80 ColuM. L. REV. 943, 978-82 (1980).

116. Under the Administrative Procedure Act, administrative law judges, who do the bulk of agency adjudication, are "employees" removable "for good cause." 5 U.S.C. $\$ 7521$ (a) (1982). ALJ's are not agency heads falling under Buckley's substantive definition of "officer." Nor are they close advisors to the President, instrumental in taking care to execute the laws on his behalf. It thus seems likely that their status as employees, subject to removal only upon the grounds specified by Congress, would remain after incorporation.

Two factors should dispel concern about mixing politics with adjudication if the President is permitted to remove agency officers, notably Commissioners, who now often review agency adjudication. First, such mixing already occurs. The intermingling of rulemaking and adjudication within independent agencies has already politicized the officers making the review. See, e.g., Association of Nat'l Advertisers v. FTC, 627 F.2d 1151 (D.C. Gir. 1979), cert. denied, 447 U.S. 921 (1980) (FTC Commissioner, former member of congressional committee staff, permitted to participate in agency rulemaking absent "irreparably closed mind"). Also, courts have recognized the political components of adjudicatory decisions of some independent agencies, especially the NLRB. See NLRB v. WymanGordon Co., 394 U.S. 759, 765 (1969) (plurality opinion); see also Scalia, supra note 43, at 407 n.252 (difference in policy component between rulemaking and adjudication not great).

Second, several options are open to those who wish to insulate agency adjudication from the presidential removal power. Congress can at least sometimes provide for decisions to be final below the agency head level. See J. MASHAw, supra note 46, at 202 (suggesting such a policy for disability claims). Congress can provide for Article III review directly from the ALJ level. Finally, Congress can adopt one of the various proposals for an Administrative Court. See B. ScHWARTz, ADMINISTRATIVE LAW 322-23 (1976).

117. One significant lesson of both Humphrey's Executor and Myers, Administratrix v. United 
action can impose political costs even on actions within a president's legal power. ${ }^{118}$ Such a political check may be especially effective concerning high-visibility positions such as Chairman of the Federal Reserve Board. ${ }^{110}$ The existence of legal and political checks, and the separation of administrative agencies from the likely sources of excessive presidential power, combined with the many arguments favoring incorporation, may well assuage the fears of those generally reluctant to cede the President new powers.

\section{ConcLusion}

The decline of expertise and impartiality, and the rise in importance of presidential coordination of and accountability for agencies, today combine to justify incorporation on functionalist grounds. Three formalist arguments also favor incorporation: the anomalous position of independent agencies in a post-functionalist legal landscape; the renascent tripartitism of the Court; and the constitutional holding that agency heads are officers, and thus, absent a distinction between executive and independent agencies, must be executive officers removable by the President.

The effects of incorporation would include the removability at will by the President of now-independent officers, and his ability to issue executive orders binding on now-independent agencies. Other possible effects would be a centralization of the power to bring suit in the name of the United States, and the preservation of the possibility of purely investigatory agencies outside of the executive branch. The practice of independent agencies, the perceptions of that practice, and the functionalism that permitted their existence have all undergone great shifts in the half-century since Humphrey's Executor. If some new basis for independence is not

States (as the case is fully captioned) is in the titles. Suit for back pay is an unfulfilling remedy-one can literally die waiting for relief. Prospects of judicial relief may thus be less important in fights over removal than the perceptions of the political actors as to who has legitimate power to remove.

118. For instance, there are historical examples of executive branch officials, within the removal power of the President, who survived in office based on political support. See W. GeLlHORN \& C. Byse, Administrative Law: Cases and Comments 132-33 (6th ed. 1974); L. Fisher, Constitutional Conflicts between Congress and the President 94-98 (1985).

119. The possibly high political cost of removing a Federal Reserve Board Chairman suggests that the effective independence of the Fed may not change very much after incorporation. Three additional arguments counteract any initial distaste for incorporation of the Fed. First, the change may not matter. The Fed has rarely departed from presidential policy for any length of time. Kilborn, Even the Upright Fed Can Sometimes Nod to Politics, N.Y. Times, June 19, 1983, § 4, at 4, col 3. Second, the change may not matter much. Any costs of incorporating the Fed may be outweighed by the benefits described elsewhere in this Note. Third, if the change matters, it may be for the best. Both Democrats and Republicans have noted the incongruity of a Fed that is accountable to the financial community rather than to elected officials. Hershey, The Fed Draws Fire From Many Fronts, N.Y. Times, Feb. 24, 1985, § 4, at 5, col. 1; Nichols, Remove the Freedom to Snub Congress, N.Y. Times, Aug. 7, 1983, § 3, at 2, col. 4 . 
found, then the incorporation advocated by this Note seems the only principled, and most desirable, alternative.

-Peter P. Swire 